\title{
Systemic toxicity to local anesthesia in an infant undergoing circumcision
}

\section{Sünnet olacak infantta lokal anestezik sistemik toksisitesi}

\author{
Ayşe Belin ÖZER, Ömer Lütfi ERHAN
}

\section{Summary}

A circumcision was planned for a four-month-old infant under local anesthesia. After the application of lidocaine, the infant stopped crying, and then generalized tonic-clonic convulsions and a diffuse erythematous rash developed. The patient was immediately monitored, ventilation was provided, and $1 \mathrm{mg}$ midazolam was given intramuscularly. After insertion of a cannula, sodium thiopental $50 \mathrm{mg}$ was given intravenously, the patient's convulsions were controlled, and endotracheal intubation was performed. The patient was extubated 30 minutes later. However, the patient was re-intubated due to his noisy breathing, and $10 \mathrm{mg}$ prednisolone was given intravenously due to mild edema seen in the larynx during endotracheal intubation. Two hours after the second intubation, the patient started to breath spontaneously and opened his eyes; he was extubated and transferred to the intensive care unit. Two days later the patient was discharged. Systemic toxicity to the local anesthesia was considered in this patient. All precautions need to be considered during the application of local anesthesia in pediatric patients, including proper indication, monitoring of the patient in the preoperative period, establishment of venous access, and readiness to apply cardiopulmonary resuscitation in the event of local anesthetic toxicity. The maximum dose of local anesthesia should be considered and it should be diluted during application.

Key words: Convulsion; infant; lidocaine; local anesthetic toxicity.

\section{Özet}

Dört aylik infanta lokal anestezi altında sünnet planlandı. Lokal anestezi uygulandıktan sonra hastanın ağlaması durdu, jeneralize tonik klonik konvulzyonlar ve yaygın eritematöz döküntü oluştu. Hemen $\% 100 \mathrm{O}_{2}$ ile maske ventilasyonu sağland, monitorize edildi ve intramüsküler olarak $1 \mathrm{mg}$ midazolam uyguland. Damar yolu açıldıktan sonra $50 \mathrm{mg}$ sodyum tiyopental intravenöz yoldan uygulandı ve konvülzyonlar kontrol altına alındı ve endotrakeal entübasyon gerçekleştirildi. Entübasyondan 30 dakika sonra basta ekstübe edildi. Fakat gürültülü solunumu olması üzerine basta tekrar entübe edildi ve endotrakeal entübasyon esnasinda larenksin hafif ödematöz olduğu gözlendiğinden $10 \mathrm{mg}$ prednizolon intravenöz yoldan uygulandı. İkinci entübasyondan yaklaşık iki saat sonra spontan olarak soluyan ve gözlerini açan hasta ekstübe edilerek yoğun bakım ünitesine alındı. Hasta iki gün sonra taburcu edildi. $\mathrm{Bu}$ hastada lokal anestezik sistemik toksisitesi düşünüldü. Pediatrik hastada lokal anestezi uygulanırken endikasyonunun doğru olması, ameliyat öncesi dönemde hastanın monitorize edilmesi, damaryolunun açılması, lokal anestezik toksisitesi gelişme ibtimaline karşı CPR uygulaması dabil tüm önlemlerin alınmış olması gerekir. Uygulama sırasında ise lokal anesteziğin maksimum uygulama dozları dikkate alınmalı ve dilüe edilerek kullanılmalıdır.

Anahtar sözcükler: Konvülziyon; infant; lidokain; lokal anestezik toksisitesi. 


\section{Introduction}

Local anesthetic drugs, which are usually accepted as safe, may cause toxic effects if overdose occurs or in the case of inappropriate use. There are two systems involved when local anesthetics display toxicity: the central nervous system (CNS) and the cardiovascular system (CVS). Firstly, excitation indications such as convulsions occur followed by inhibition indicators such as apnea and loss of consciousness in the CNS. However in the CVS, the first indication is tachycardia and hypertension followed by bradycardia, hypotension, and asystole. ${ }^{[1-3]}$

Lidocaine, one of the most commonly used local anesthetics, has an anticonvulsive effect at low doses and it is used to treat seizures in pediatric patients. However, it can cause convulsions if it is used at high doses. ${ }^{[4]}$

We present here the systemic toxicity related to local anesthesia that developed in a 4-month-old infant who was undergoing circumcision under local anesthesia.

\section{Case Report}

A circumcision was planned for a four-month-old, $8.9 \mathrm{~kg}$ male infant under local anesthesia by the surgical team. Local anesthesia with lidocaine was provided under operation room conditions. Before starting the surgical process, the patient stopped crying and started to have abnormal behavior such as shaking; the anesthesia teams were immediately informed. It was reported after evaluation that the patient had lost consciousness, had generalized tonic clonic convulsions and widely distributed erythematous rash on his whole body and his jaw was also locked. The surgical team stated that they used 2.5 ampoules from $2 \%$ lidocaine simplex. Local anesthetic toxicity and allergic reaction were considered as possible causes. The patient was monitored and his ventilation was immediately provided by $100 \%$ $\mathrm{O}_{2}$ mask and the blood vessel way was cut down. The heart rate of the patient was 170 beats/min, and his $\mathrm{SpO}_{2}$ was $95 \%$. Until the cannula was placed vascularly, $1 \mathrm{mg}$ midazolam was given intramuscularly to help combat his convulsions. The intravenous line was then provided endotracheal intubation was performed, but the first try was unsuccessful due to the patients locked jaw. After the placement of the intravenous cannula, $50 \mathrm{mg}$ of intravenous sodium thiopental was given and the patient's convulsions were controlled. Mechanical ventilation was continued by endotracheal intubation. By listening, breath sounds were normal and the rash on his skin disappeared on its own. The spontaneous breath became normal approximately 15 minutes later after applying sodium thiopental and he was extubeted approximately 30 minutes later due to the reaction of endotracheal tube. After extubation, the patient was re-intubated owing to his noisy breathing and because he was not quite conscious. $10 \mathrm{mg}$ prednisolone was given intravenously due to light odemateuse seen in the larynx during endotracheal intubation. Two hours later after the second intubation, the patient started to breath spontaneously and opened his eyes; he was extubated and transferred to the intensive care unit. Two days later the patient was discharged after he was followed one day in the ICU.

When the story of the patient was evaluated retrospectively it was established that the patient had general anesthesia for cystoscopic manipulation because of vesicoureteral reflux 2 months prior to his planned circumcision. It was evaluated as ASA-I during the preoperative period and it was observed that there was no negativity during anesthesia. The patient had no known disorders including convulsion in the anamnesis obtained from his family. 2.5 ampoules from $2 \mathrm{ml}$ of $2 \%$ lidocaine were applied which translates to $100 \mathrm{mg}$ and an $11 \mathrm{mg} / \mathrm{kg}$ lidocaine dose.

\section{Discussion}

Different anesthesia methods such as general, local, caudal anesthesia, and dorsal penile block can be performed for circumcision application according to the preference and experience of the surgeon and anesthetist. ${ }^{[5-8]}$ In our clinic, the surgeons prefer to apply local anesthesia depending on the patient's age and orientation or they call us for anesthesia application. In this patient, the surgical team applied local anesthesia without monitoring the patient and inserted an intravenous cannula into the patient. Local anesthesia application without preparation in a patient without cooperation may cause delayed interferences leading to possible complications. How- 
ever, the patient's life was saved because the application was done in operating room conditions.

Local anesthetics drugs are usually accepted as safe but they can cause toxic effects when not used appropriately and overdose occurs. The potency of lidocaine and its non-desired effects on cardiac contractility is one in four, and its adverse effects on the CVS occur in one out of sixteen patients compared to bupivacaine. The probability that the ECG will become normal is one in eight when using lidocaine compared to bupivacaine. Therefore, it can be stated that the toxic effects of lidocaine is less than bupivacaine. ${ }^{[9,10]}$ It is known that the maximum dose of the simplex form of lidocaine was $4.5 \mathrm{mg} /$ $\mathrm{kg}$ while $7 \mathrm{mg} / \mathrm{kg}$ for the adrenaline form in adults. ${ }^{\text {[1] }}$ But, in pediatric population, dose of lidocaine is $3 \mathrm{mg} / \mathrm{kg}{ }^{\left[{ }^{[12]}\right.}$ Approximately $11 \mathrm{mg} / \mathrm{kg}$ dose without adrenaline was applied to our patient. That means the local anesthetic toxicity was developed owing to overdose.

It was stated that using lidocaine with distinct application techniques can cause the development of systemic toxicity in pediatric patients. Some of these results come from performing on body areas where absorption is high and the others are due to overdose use. ${ }^{[2,10,13]}$

Benzodiazepines are the first line of anticonvulsants for treatment of acute seizures. Diazepam is one of the most frequently used benzodiazepines both intravenously as well as rectally. It cannot be used intramuscularly as it is a lipophilic agent with erratic intramuscular absorption. Thus in a convulsing child, precious time is spent on getting an intravenous access or for per rectal catheterization. Midazolam is a lipid soluble benzodiazepine with 3-4 times more potency as diazepam on a milligram-tomilligram basis and can be given IV, rectal or intramuscular. Bio-availability of midazolam is approximately $90 \%$ post intramuscular administration. ${ }^{[14]}$ Intramuscular midazolam rapidly terminates seizures in children and adults and it is demonstrated that it is at least as safe and effective as intravenous lorazepam and diazepam. ${ }^{[14-16]}$ Avarage dose of intramuscular midazolam is $0.12 \mathrm{mg} / \mathrm{kg}(0.07-0.21) .{ }^{[16]}$ In our patient, midazolam dose is compatible with the average dose.
Developing an allergic reaction related to local anesthesia is usually expected when applying ester group local anesthesia. Developing allergic reaction is rare amid group local anesthetics. ${ }^{[1]}$ In our patients erythematous rash occurred on the whole body and disappeared itself. Breath sounds were normal upon listening and there was tachycardia but not hypotension. Therefore, it was not certain whether allergic reaction developed and since there were no symptoms, no intervention was thought to be done. It is thought that the light edematous difference during the second intubation may have been related to traumatized tissues because of contractions and locked jaw of the patient during the first intubation attempt.

All precautions need to be considered during local anesthesia in pediatric patients including proper indication, monitoring of the patient in the preoperative period, opening the blood vessel way, and being ready to apply CPR for the possibility developing local anesthetic toxicity. The maximum dose of local anesthesia should be considered and it should be used by diluting during application.

\section{Conflict-of-interest issues regarding the author- ship or article: None declared.}

\section{Peer-rewiew: Externally peer-reviewed.}

\section{References}

1. Berde CB, Strichartz GR. Local anesthetics. In: Miller RD, Eriksson LI, Fleisher LA, Wiener-Kronish JO, Young WL, editors. Miller's anesthesia. 7th ed., Philadelphia: Churchill Livingstone; 2010. p. 913-940. CrossRef

2. Nelsen J, Holland M, Dougherty M, Bernad J, Stork C, Marraffa J. Severe central nervous system and cardiovascular toxicity in a pediatric patient after ingestion of an over-the-counter local anesthetic. Pediatr Emerg Care 2009;25(10):670-3. CrossRef

3. Erhan ÖL, Demir S. Bebekte prilocaine $(70 \mathrm{mg} / \mathrm{kg})$ uygulanması sonucu solunum arresti (olgu sunumu). Fırat Üniversitesi Dergisi (Sağlık Bilimleri) 1991;5(2):77-9.

4. van den Broek MP, Huitema AD, van Hasselt JG, Groenendaal $F$, Toet MC, Egberts TC, et al. Lidocaine (lignocaine) dosing regimen based upon a population pharmacokinetic model for preterm and term neonates with seizures. Clin Pharmacokinet 2011;50(7):461-9. CrossRef

5. Fontaine $P$, Dittberner D, Scheltema KE. The safety of dorsal penile nerve block for neonatal circumcision. J Fam Pract 1994;39(3):243-8.

6. Beyaz SG. Comparison of Postoperative Analgesic Efficacy of Caudal Block versus Dorsal Penile Nerve Block with Levobupivacaine for Circumcision in Children. Korean J Pain 2011;24(1):31-5. CrossRef

7. Rosen M. Anesthesia for ritual circumcision in neonates. Paediatr Anaesth 2010;20(12):1124-7. CrossRef 
8. Sasmaz I, Antmen B, Leblebisatan G, Şahin Karagün B, Kilinç $Y$, Tuncer R. Circumcision and complications in patients with haemophilia in southern part of Turkey: Çukurova experience. Haemophilia 2012;18(3):426-30. CrossRef

9. Reiz S, Nath S. Cardiotoxicity of local anaesthetic agents. Br J Anaesth 1986;58(7):736-46. CrossRef

10. Lönnqvist PA. Toxicity of local anesthetic drugs: a pediatric perspective. Paediatr Anaesth 2012;22(1):39-43. CrossRef

11. Morgan GE, Mikhail MS, Murray MJ, Larson CP. Local anesthetics, Clinical anesthesiology. 3rd ed., Los Angeles: The McGraw-Hill Companies; 2002. p. 253-344.

12. Çelik M, Soyer ÖU, Şekerel BE. Lidokaine bağlı alerji veya toksisite? Astım Allerji İmmünoloji 2008;6(1):22-4.

13. Menif K, Khaldi A, Bouziri A, Hamdi A, Belhadj S, Ben Jaballah
N. Lidocaine toxicity secondary to local anesthesia administered in the community for elective circumcision. Fetal Pediatr Pathol 2011;30(6):359-62. CrossRef

14. Shah I, Deshmukh CT. Intramuscular midazolam vs intravenous diazepam for acute seizures. Indian J Pediatr 2005;72(8):667-70. CrossRef

15. Silbergleit R, Durkalski V, Lowenstein D, Conwit R, Pancioli A, Palesch $Y$, et al. Intramuscular versus intravenous therapy for prehospital status epilepticus. N Engl J Med 2012;366(7):591600. CrossRef

16. McDonagh TJ, Jelinek GA, Galvin GM. Intramuscular midazolam rapidly terminates seizures in children and adults. Emergency Medicine 1992;4(2):77-81. CrossRef 